\title{
Prolonged faecal excretion of poliovirus in a nurse with common variable hypogammaglobulinaemia
}

\author{
Siraj A. Misbah, Patrick A. Lawrence', John B. Kurtz ${ }^{2}$ and Helen M. Chapel \\ Department of Immunology, John Radcliffe Hospital, Oxford, 'Department of Occupational Health, \\ Radcliffe Infirmary, Oxford and ${ }^{2}$ Department of Virology, John Radcliffe Hospital, Oxford, UK
}

\begin{abstract}
Summary: A nurse with common variable hypogammaglobulinaemia was found to excrete a non-vaccine strain type II poliovirus for almost a year following a bout of gastroenteritis. Attempts were made to halt intestinal carriage of the virus in view of the possible risk of spread to immunocompromised patients and the risk of paralytic poliomyelitis to the patient himself.

Three doses of killed Salk vaccine failed to stimulate salivary anti-polio antibodies. Excretion of the virus ceased spontaneously just before oral immunoglobulin containing high titres of antibodies to polio virus was used to halt virus excretion.
\end{abstract}

\section{Introduction}

In contrast to individuals with defective cellmediated immunity viruses in general do not pose a major problem to antibody deficient patients. ${ }^{1}$ Certain enteric viruses (ECHO, poliovirus, rotavirus), however, constitute an exception and chronic enteroviral meningo-encephalitis due to echovirus is a well recognized entity in patients with $\mathrm{X}$-linked agammaglobulinaemia. ${ }^{2}$ Enteroviral meningoencephalitis in patients with common variable hypogammaglobulinaemia (CVH), although much rarer, has been described in at least two patients. ${ }^{2}$ Enteric infection with Coxsackie virus in an agammaglobulinaemic male infant associated with prolonged faecal carriage for 10 weeks has also been reported. This infant subsequently developed chronic meningoencephalitis due to the same serotype of Coxsackie virus. ${ }^{3,4}$

We wish to report the case of a nurse with $\mathrm{CVH}$ who was found to excrete poliovirus for almost a year following a bout of gastroenteritis. Attempts were made to eliminate carriage of the virus in view of his profession.

\section{Case report}

A Caucasian male first presented at the age of 17 years in 1969 for investigation of delayed puberty associated with intermittent diarrhoea. The only significant findings on clinical examination at this stage were small testes, scanty pubic hair and absent facial and axillary hair. Detailed endo-

Correspondence: S. Misbah, M.R.C.P.

Accepted: 15 October 1990 crinological and metabolic investigations were all within normal limits (including dynamic tests of the hypothalamic-pituitary-gonadal axis).

A jejunal biopsy revealed mild villous atrophy associated with hypolactasia but no organisms were seen. A barium meal and follow-through showed flocculation and oedema in the small bowel. These abnormalities were thought not to warrant any therapeutic intervention and over the next year he spontaneously attained puberty.

A second jejunal biopsy performed in 1970 on account of recurrent diarrhoea now showed nodular lymphoid hyperplasia with Giardia lamblia infestation in addition to mild villous atrophy. His giardiasis was treated with metronidazole and subsequent jejunal biopsies revealed complete clearance of giardia. Hypogammaglobulinaemia was diagnosed at this stage (Table I).

On subsequent follow-up he remained extremely well, achieving satisfactory physical growth. He was then lost to follow-up from 1972 until May 1986 when he entered nursing school and was immunized with rubella vaccine. His inability to mount an immune response to rubella prompted referral to the immunology department. The results of investigations at this stage (May 1986) are depicted in Table I. He had been fully immunized in infancy, having received a complete course of triple vaccine (diphtheria, pertussis, tetanus) and oral polio vaccine [Sabin]. Haematological indices, liver and renal function tests were all normal.

Although he did not suffer from recurrent infections, it was thought prudent at this stage to give him replacement immunoglobulin in view of his occupation as a nurse. Immunoglobulin replacement was commenced in January 1987 via the 
Table I Summary of investigations

\begin{tabular}{|c|c|c|c|}
\hline & & 1970 & 1986 \\
\hline Serum immunoglobulins & $\begin{array}{l}\text { IgG } \\
\text { IgA } \\
\text { IgM }\end{array}$ & $\begin{array}{l}2.8 \mathrm{~g} / \mathrm{l} \text { (normal range } 8-16 \mathrm{~g} / \mathrm{l}) \\
0.48 \text { (normal range } 1.4-4.2 \mathrm{~g} / \mathrm{l}) \\
\text { Undetectable }\end{array}$ & $\begin{array}{l}1.0(\text { normal range } 7.2-19.0 \mathrm{~g} / \mathrm{l}) \\
<0.01(\text { normal range } 0.8-5.0 \mathrm{~g} / \mathrm{l}) \\
0.1(\text { normal range } 0.5-2.0 \mathrm{~g} / \mathrm{l})\end{array}$ \\
\hline \multicolumn{2}{|l|}{ Salivary IgA } & Absent & Present \\
\hline \multicolumn{2}{|l|}{$\begin{array}{l}\text { Secretory piece } \\
\text { DTH skin response to: }\end{array}$} & ND & Present \\
\hline & $10 \mathrm{~mm}$ (positive) & Neg \\
\hline \multicolumn{2}{|l|}{ Candida albicans } & ND & Neg \\
\hline \multicolumn{2}{|c|}{ Streptokinase-Streptodornase } & ND & Neg \\
\hline \multirow{2}{*}{\multicolumn{2}{|c|}{$\begin{array}{l}\text { DNCB sensitization } \\
\text { Specific serum antibodies to: }\end{array}$}} & ND & Positive on challenge \\
\hline & & & \\
\hline \multicolumn{2}{|c|}{ Influenza A } & $<1: 4$ & ] \\
\hline \multicolumn{2}{|l|}{ Influenza B } & $<1: 4$ & jND \\
\hline \multicolumn{2}{|l|}{ Herpes simplex } & $<1: 4$ & \\
\hline \multicolumn{2}{|l|}{ Psittacosis } & $<1: 4$ & \\
\hline \multicolumn{2}{|l|}{ Rubella } & ] & Not detected (SRH) \\
\hline \multicolumn{2}{|l|}{ Mumps } & ] & $1: 8$ (CFT) \\
\hline \multicolumn{2}{|l|}{ Measles } & & $<1: 2$ (CFT) \\
\hline \multicolumn{2}{|l|}{ Varicella zoster } & jND & $<1: 2$ (CFT) \\
\hline \multicolumn{2}{|l|}{ Tetanus } & ] & $<1: 8^{*}$ \\
\hline \multirow{2}{*}{\multicolumn{2}{|c|}{$\begin{array}{l}\text { E. coli } \\
\text { Diphtheria }\end{array}$}} & ] & $<1: 8$ \\
\hline & & ] & $<1: 8^{* *}$ \\
\hline \multirow{2}{*}{\multicolumn{2}{|c|}{$\begin{array}{l}\text { Pneumococcus } \\
\text { Schick Test }\end{array}$}} & 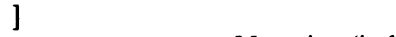 & $<1: 8^{* *}$ \\
\hline & & \multicolumn{2}{|c|}{$\begin{array}{c}\text { Negative (indicating adequate } \\
\text { humoral immunity to } C \text {. diphtheriae] }\end{array}$} \\
\hline
\end{tabular}

*Tetanus antibodies rising to only 1:32 following immunization. ${ }^{* *}$ No change after immunization with diphtheria and pneumococcus. DNCB-Dinitrochlorobenzene; ND-not done; CFT-complement fixation test; SRH-single radial haemolysis; DTH-delayed type hypersensitivity.

intramuscular route following an initial intravenous loading dose.

In July 1987, following a bout of gastroenteritis, a stool was sent for culture and an enterovirus was cultured. The patient was nursing on the paediatric wards at the time. This was found to be a Type II poliovirus which did not react against monoclonal antibodies raised against the Sabin Type II virus. (Personal communication, Dr Schild, National Institute for Biological Standards, Colindale). It was not known whether the virus might have arisen from a vaccine strain with subsequent antigenic drift or whether it was a wild type strain.

On account of the possible risk of transmission of the virus to his contacts, we attempted to eliminate the virus. There was a significant neutralizing titre of antibody to this strain of virus in his blood [ $1: 256]$, because of intramuscular immunoglobulin replacement, but no specific antibody was detected in saliva. In immunocompetent individuals killed polio vaccine [Salk] is known to induce and boost secretory IgA antibodies. ${ }^{5}$ Since he had detectable salivary $\operatorname{IgA}$ and secretory piece, attempts were made to provoke a specific mucosal IgA response. He was given (Salk) killed vaccine intradermally $(0.1 \mathrm{ml})$. It was of interest that there was no cutaneous delayed type hypersensitivity response. Examination of the stools 3 weeks later showed that the poliovirus was still present.

Further subcutaneous boosts of the Salk vaccine $(0.1 \mathrm{ml})$ were given 1 week and 4 weeks later, but $\frac{0}{3}$ excretion of the enterovirus continued. Repeat skin tests were negative and his salivary antibody titres to poliovirus remained undetectable.

The use of the live oral polio vaccine was precluded by his generalized antibody deficient state; there are several previous reports of paralytic 3 . poliomyelitis in hypogammaglobulinaemic pat- $\hat{\rho}^{-}$ ients who were immunized with oral polio vaccine. $6 \frac{3}{3}$ We therefore planned to give him oral immuno-o globulin in July 1988, using a preparation (Gam-? magard) which contained high titres of neutralizingo antibody to this particular virus $(1: 1000)$, but he spontaneously stopped excreting the virus approx- $\sigma$ imately a year after it was first detected, just before N this therapeutic intervention.

\section{Discussion}

Prolonged faecal excretion of enteric viruses in patients with antibody deficiency has been docu-o mented previously. In particular, poliovirus was $\vec{\Phi}$ reported to have been excreted by two hypogam- $-\frac{?}{\mathbb{D}}$ 
maglobulinaemic children for periods of up to 32 and 21 months, in spite of replacement therapy with gammaglobulin. ${ }^{1}$ IgA deficient individuals have also been reported to excrete poliovirus for up to 10 weeks after oral polio vaccination in contrast to normal controls who had stopped excreting the virus by this stage. ${ }^{7}$

Increased neurovirulence of the poliovirus during prolonged faecal shedding has been documented in both agammaglobulinaemi and normal children. ${ }^{8.9}$ Our patient continued to excrete poliovirus for approximately a year, posing serious occupational health problems. In view of the potential risk of spread, especially to immunocompromised patients, and the implications of possible changes in neurovirulence to himself, it was important that excretion of the virus should be halted as soon as possible. He was advised not to nurse immunocompromised patients until this had been achieved.

Although we did not use intravenous immunoglobulin (IVIg) in attempts to halt viral excretion,

\section{References}

1. Working party on Hypogammaglobulinaemia. Hypogammaglobulinaemia in the United Kingdom. Medical Research Council special report series 310 . Her Majesty's Stationery Office. London. 1971, pp. 25, 80.

2. McKinney, R.E., Katz, S.L. \& Wilfert, C.M. Chronic enteroviral meningoencephalitis in agammaglobulinaemic patients. Rev Infect Dis 1987, 9: 334-356.

3. Johnson, J.P., Yolken, R.H., Goodman, D., Winkelstein, J.A. \& Nagel, J.E. Prolonged excretion of Group A Coxsackie virus in an infant with agammaglobulinaemia. $J$ Infect Dis 1982, 146: 712.

4. O'Neil, K.M., Modlin, J.F., Lock, T.M. \& Winkelstein, J.A. Coxsackie A15 enteritis and encephalitis in agammaglobulinaemia. Pediatric Res 1986, 20: 318A.

5. Svennerholm, A.M., Hanson, L.A., Holmgren, J. et al. Antibody responses to live and killed poliovirus vaccines in the milk of Pakistani and Swedish women. J Infect Dis 1981, 143: 707-711. the use of high dose IVIg would be a therapeutic option worth considering in a future case. Our experience in this case, however, suggests that in the absence of active inflammation there is no significant passage of serum IgG into the gut epithelium and that specific IgG in the serum is incapable of neutralizing viruses in the mucosal epithelium.

We would also recommend that family members and close contacts should have their serum antibody titres to poliovirus measured. Those who lack antibodies to poliovirus should be immunized with killed vaccine (Salk). The use of live polio vaccine in this instance could carry the risk of re-infecting the immunodeficient patient.

\section{Acknowledgement}

We wish to thank Angela Welby for typing the manuscript.

6. Chang, T.W., Weinstein, L. \& McMahon, H.E. Paralytic poliomyelitis in a child with hypogammaglobulinaemia. Pediatrics 1966, 37: 630-636.

7. Savilahti, E., Klemola, T., Carlsson, B., Mellander, L., Stenvik, M. \& Hovi, T. Inadequacy of mucosal IgM antibodies in selective IgA deficiency: Excretion of attenuated poliovirus is prolonged. J Clin Immunol 1988, 8: 89-94.

8. Hara, M., Saito, Y., Komatsu, T. et al. Antigenic analysis of polioviruses isolated from a child with agammaglobulinaemia and paralytic poliomyelitis after Sabin vaccine administration. Microbiol Immunol 1981, 25: 905-913.

9. Evans, D.M.A., Dunn, G., Minor, P.D. et al. Increased neurovirulence associated with a single nucleotide change in a noncoding region of the Sabin type 3 poliovaccine genome. Nature 1985, 314: 548-550. 